\title{
Voters' Motivation for Selecting the Party Leader: The Case of the Italian Democratic Party
}

\author{
Stefano Rombi * \\ Department of Political and Social Sciences, University of Cagliari, Cagliari, Italy
}

Political parties suffer from a lasting, consolidated and, probably, irreversible crisis. However, they have begun a laborious process of adaptation which, among other things, has led to the spread of some new organizational practices. In general terms, looking at the party on the ground, we have seen a significant spread of inclusive procedures in party decision-making, which, in other words, has meant a strengthening of intra-party democracy. In particular, the inclusion of party members and, sometimes, sympathizers concerns not only the formulation of a policy position, but also the selection of party candidates and leadership. This article focuses on the inclusive process of leadership selection of the Italian Democratic Party (DP) occurred in 2013, 2017 and 2019. Since its inception, the Democratic Party has introduced the figure of the supporter, i.e. a voter not formally enrolled in the

Edited by:

Eva. H. Önnudóttir, University of Iceland, Iceland

Reviewed by: Aldo Paparo, Guido Carli Free International University for Social Studies, Italy Sorina Soare, University of Florence, Italy

${ }^{*}$ Correspondence: Stefano Rombi srombi@unica.it

Specialty section: This article was submitted to Elections and Representation, a section of the journal Frontiers in Political Science

Received: 15 July 2021 Accepted: 15 September 2021 Published: 29 September 2021

Citation:

Rombi S (2021) Voters' Motivation for Selecting the Party Leader: The Case of the Italian Democratic Party.

Front. Polit. Sci. 3:742232. doi: 10.3389/fpos.2021.742232 party but authorized to participate in a number of internal decision-making processes, including the selection of the party leader. Using the survey data from the research group Candidate and Leader Selection (CLS), the article explores the relationship between selectors and the primaries, looking particularly to the motivations behind the choice of vote. The analysis is based on over 8,000 interviews conducted through the exit poll technique and collected from 2013 to 2019. The article shows that voters self-positioning on the left-right axis and their strategic orientation are, in all three cases of primaries, the most relevant variables for explaining the selectors' motivations.

Keywords: primary elections, political parties, voting behavior, electability, personalization

\section{INTRODUCTION}

The reasons behind voters choosing one candidate over another continue to excite an increasing number of researchers in different fields of the social sciences from political science to sociology and from socio-political psychology to economics (Bartels, 2000; Lewis-Beck et al., 2008; Ohr and Oscarsson, 2011). The research question underlying this literature can take on a dual role. On the one hand, it is possible to ask how the voter's motivations determines the choice of vote, that is, whether and to what extent a different motivation also implies a different vote (Van Spanje and De Vreese, 2011; Blumenstiel and Plischke, 2015). Alternatively, one can ask what voter characteristics motivate the choice of vote in one way and not another (Sozzi, 2015; Smith and Hanley, 2018). This last approach allows the researcher to draw a profile of the voters based on the motivation behind their vote. 
This article will adopt the second perspective, focusing on the voting motivations indicated by the participants in the leadership primaries, organized by the Italian Democratic Party (PD) in 2013, 2017, and 2019. ${ }^{1}$

Although the study revolving around the current selection of candidates has a long tradition that goes beyond the borders of the United States (US), there has been very little research done on reconstructing the characteristics of the selectors, their preferences, and the motivations behind their choices (Sozzi, 2015). Therefore, this article can help increase the knowledge in an under-investigated area of electoral studies. From a methodological perspective, this article is based on a pooled analysis through which, on the one hand, we will build the profile of the selector according to the motivation behind their choice of vote; on the other hand, using a multinomial logistic regression model, we will understand which variables are most relevant in explaining the use of one motivation or another.

As anticipated, the analysis will focus on the case of the Italian Democratic Party whose primary elections are open to the vote of the supporter (Pasquino, 2009; Pasquino and Venturino, 2010; Pasquino and Venturino, 2014; Sandri and Seddone, 2015; De Luca and Fasano, 2018; Rombi et al., 2019). In a European context in which primary elections are becoming more and more popular among parties, the case of PD is particularly relevant for at least two reasons. Firstly, the PD has included the primaries in its statute and, consequently, has selected its first leader, in 2007, through that selection mechanism. For the PD, the primaries constitute an organizational and identity element. Secondly, since its birth, the PD has organized more than 1.000 primaries, at municipal, regional and national level, both for selecting candidate and leaders.

Among the five primaries for the PD leadership, we examined those of 2013, 2017 and 2019 for two reasons: firstly, there is a big difference in the intra-party and inter-party context among the three primaries; secondly, unlike the 2007 and 2009 primaries, those examined were investigated using a very similar questionnaire. The first reason increases the possibility of generalizing the results of the analysis, since it allows us to understand the behavior of selectors in the same electoral arena, but in different political contexts. The second reason facilitates the comparison of the three cases examined, while their inclusion in the analysis of 2007 and 2009 primaries would have made the results less reliable. ${ }^{2}$

To sketch out the political context, it is useful to know that in 2013 the competition took place a few months after the PD unsatisfactory result in the parliamentary elections, so much so that the primary's victory went to an outsider-Matteo Renzi-who had been defeated a year earlier in the coalition primaries. In 2017 the primaries were held about a year before the

\footnotetext{
${ }^{1}$ The PD leadership selection procedure is complex and the open primaries constitute only a phase, albeit certainly the most important one, of a mechanism that also involves the party members and the National Assembly (Venturino, 2019).

${ }^{2}$ The database relating to this article has been derived from the surveys organized by the Candidate and Leader Selection research group.
}

2018 parliamentary elections and a few months after the defeat suffered by Renzi-at the time Prime Minister-at the constitutional referendum. That primaries were aimed at relaunching the political figure of a leader in free fall. Finally, in 2019 the primaries took place after the heavy defeat of the PD in the parliamentary elections of 2018, and led, with the victory of Zingaretti, to a substantial return to the past, in opposition to the Renzi's phase.

Although there are some systematic analyses of primaries based on survey data (Seddone et al., 2020; Venturino and Seddone, 2020), "there are very few individual-level analyses of the behavior of voters in primaries» (Simas, 2017, p. 1). This article, therefore, contributes to filling the gap in this line of research.

In the next section, we will focus on the hypotheses put forward by the literature in relation to the determinants of the vote and the reasons for voting and also look at the treatment of the variable "motivations" within the questionnaires administered to the selectors. In the third section, after providing some information about the methodology of the research, we will build a profile of the selectors, characterizing them according to their motivation type. The results of the inferential model will be discussed in the fourth section and follow up with some concluding remarks.

\section{VOTERS' MOTIVATIONS IN PRIMARY ELECTIONS}

The study of the formation of electoral preferences and their translation into voting choices is a pillar of political science, in general, and in electoral studies, in particular. If we look at the general election, early studies on electoral behavior have followed two alternative approaches. On the one hand, the choice of vote has been interpreted through the Michigan School's socialpsychological approach and starting with The American Voter, it has been focused on long-term party identifications. However, it has been studied following the sociological approach of the Columbia School, whose first and fundamental product was the volume The People's Choice, based on the influence exerted on electoral behavior by the social groups to which the voter belongs. Both schools based their studies on the persistence of long-term attitude based on social position or partisanship. When those predisposition declined, the basis of electoral studies shift to short-term factors, such as voters' opinion on issues and candidate image (Dalton and Klingemann, 2007).

Primary elections in general, and those for the leadership of the $\mathrm{PD}$ in particular, are an atypical electoral context. The primaries, in fact, fit perfectly with the emergence of centered candidate parties (Wattenberg, 1990), in which the image of the leader acquires a very relevant weight in every electoral competition (McAllister, 2007; Garzia, 2014). The mediatization of politics (Mazzoleni and Schulz, 1999; Esser and Strömbäck, 2004) and the erosion of traditional social cleavages (Ford and Jennings, 2020) have increased the centrality of leaders both as an organizational and electoral resource. In this context, open primary elections are an 
attempt to democratize the selection of the leader, that is the main political resource currently available to the parties, also in order to offer supporters alternative opportunities for militancy (Scarrow, 2014). This mechanism reinforces the process of personalization of politics, with respect to which the primaries represent both a response and a booster.

Examining the voting motivations essentially means understanding what guided the selector's voting choice for a given candidate. The primaries, in fact, are participated by selectors which differs from each other in terms of closeness to the party, strategic orientation, sociographic characteristics. Therefore, the basic argument of this article is that the motivations for voting in primary elections are explained mainly by the socio-political characteristics of the selectors.

The reasons for voting in the primaries can be grouped into two categories: soft reasons and hard reasons (Sozzi, 2015; Seddone and Sozzi, 2018; Seddone, 2019). The former include motivations related to values, ideological adherence and longterm identity ties with the party. The latter, on the other hand, include instrumental-linked, for example, to the possibility of the chosen candidate to win the subsequent general elections-and short-term motivations, connected for example to the personal characteristics of the leader (Markus and Converse, 1979; Markus, 1982; Lau and Redlawsk, 2001; Barker et al., 2006).

While motivations based on "values" may relate to virtually all types of election, other reasons can be traced back to the very nature of primary elections, even if they are aimed at selecting a party leader. To learn more about what these additional (hard) reasons for voting are, we should refer to two aspects. On the one hand, we must remember that primaries, which establish an unmediated link between selectors and candidates, are a particularly attractive tool for contemporary personalized politics (Poguntke and Webb, 2005; Samuels and Shugart, 2010). On the other hand, you have to consider that primaries are called upon to select a candidate who will have to challenge opponents in subsequent elections. This also applies to the direct selection of party leadership, especially as the PD statute provides that the secretary is also the party's "candidate" for the presidency of the Council. ${ }^{3}$

The first argument refers to reasons based on personalization. Although often accused (not always wrongly) of promoting plebiscitary politics (Ignazi, 2019), primaries, especially in the Italian case, cannot be held responsible for the genesis of personalization in politics. Not only because a certain degree of personalization has always characterized politics (Pasquino, 2016) but above all because the personal and personalized Italian party par excellence was born in 1993, many years before the primaries appeared on the scene of Italian politics. It is, of course, Silvio Berlusconi's Forza Italia. Personalization then covered

3'Il Segretario nazionale rappresenta il Partito, ne esprime la leadership elettorale ed istituzionale, l'indirizzo politico sulla base della piattaforma approvata al momento della sua elezione ed è proposto dal Partito come candidato all'incarico di Presidente del Consiglio dei Ministri" (PD Statute, article 5, paragraph 1). numerous other political forces and, in any case, was mainly because of the extreme exposure to the mass media by the leaders as well as by changes in the same citizenship (Norris, 1999), party organizations, and electoral rules. This idea of bringing leadership closer to the public (Manin, 1997) has contributed to generating the direct relationship between voters and/or party members and leaders that forms the core of the concept of personalization (Calise, 2016). As is the case in other electoral contexts, the choice of vote of primary participants can be influenced by the personal characteristics of the candidate. Moreover, these characteristics do not necessarily have to concern character traits or attitudes since " voters may make inferences about character traits based on the issue and policy positions with which a candidate aligns» (Peacock et al., 2021, p. 543).

The second argument refers to reasons related to the concept of electability, i.e., the candidate's prospects of winning the general election (Abramowitz, 1989; Abramson et al., 1992; Steger, 2003, Steger, 2007). This opens the door to a strategic vote, that is, the possibility of not voting for their first preference but for the leader to whom the selector gives the best chance of defeating opponents in the general election. The literature on primaries focused both on how to measure electability (Abramowitz, 1989; Rickershauser and Aldrich, 2007) and on the number of strategic voters. Both in the Italian (Cavataio and Fasano, 2013; Carreri, 2019) and US case (Peacock et al., 2021), scholars show how electability is a relevant driver in the construction of the selectors' voting choice. This relevance, unsurprisingly, varies with the timing in which the primaries occur and the political context (Minaldi and Soare, 2018). Of course, electability is closely influenced by the opinion polls disseminated by the mass media (Erberl et al., 2017), which contributes to the formation of public opinion (NoelleNeumann, 1993), favoring the activation of a circular mechanism that is self-feeding, and ends up further strengthening the strongest candidate (Peacock et al., 2021).

The selectors' profiles will be drawn by considering three sociographic and four political variables. The former includes gender, age, and education. The latter includes the level of interest in politics, self-positioning of the selector on the left-right axis, PD membership, and their strategic orientation. Each variable corresponds to a question in the questionnaire, barring the last, which combines the attitude of the selectors toward the PD depending on the outcome of the primaries with the selectors' vote $^{4}$. The variable "strategic orientation" consists of four

${ }^{4}$ This attitude was noted by asking respondents the following question: "If the candidate you voted for in these primaries were to be defeated, how would you behave at the next elections?" The options to answer were as follows: a) I will certainly vote PD; b) I do not know, it depends on who wins the primaries; c) I will not vote for the PD. In the construction of the variable, options $\mathrm{b}$ and $\mathrm{c}$ have been merged. In the case of the choice of vote, the possible alternatives have been reduced to two: vote for the leading candidate vote for the others candidates. The second option combines those who voted for the runner-up and those who voted for the outsider. This amalgamation stems from the fact that, from the perspective of attitude toward the PD, the behavior of the runner-up selectors, and that of the outsider's selectors are completely similar. 
categories: defectionist winners; defectionist losers; loyal winners; and loyal losers. ${ }^{5}$

Based on those variables and considering the considerations made for each type of motivation, it is possible to put forward the following hypotheses:

1. Gender: no hypothesis can be put forward.

2. Age: we expect older voters to have a propensity to vote on the basis of soft reasons, by virtue of a long-term link with the party.

3. Education: we expect that the most educated selectors tend to motivate their vote on the basis of instrumental-rational reasons such as the electability of the candidate. Conversely, we expect that the less educated motivate their vote on the basis of contingent factors such as the candidate's personal characteristics.

4. Interest in politics: established that selectors are generally quite or very interested in politics, we expect interest in politics to induce selectors to vote on the basis of ideological and value-driven factors.

5. Left-right self-positioning: given their relative distance from the party's political position, we expect centrist selectors to motivate their voting choice by looking at the electability and personal characteristics of the candidates. Conversely, we expect left-wing selectors to orient their vote on ideological-value grounds.

6. PD membership: we expect PD members to have a relatively higher propensity than non-members to vote on the basis of soft reasons.

7. Strategic orientation: we assume that loyal selectors-regardless of their choice of vote-tend to vote on the basis of ideological-value motivations, given their identification with the party. Conversely, we assume that defectionists selectors-regardless of their choice of vote-tend to vote on the basis of instrumental and contingent motivations.

In the following paragraphs we will empirically verify the hypotheses just formulated.

\section{THE PROFILE OF THE SELECTORS BASED ON MOTIVATIONS}

The data examined in this article are pooled from three distinct exit poll surveys conducted between 2013 and 2019. Overall, our analysis includes 8,582 cases distributed in all Italian regions, with the sole exception of the Aosta Valley ${ }^{6}$. The 2013 primary

\footnotetext{
${ }^{5}$ Since the favorite candidate actually won the primary on all three occasions, we decided to use the label "winners" in naming the variables. The same happened in the case of the runner up and the outsider, who were actually defeated. So, in this case, we used the label "losers" when naming the variables.

${ }^{6}$ The number of questionnaires to be administered in each region was determined in proportion to the share of turnout in previous primaries. In each region, questionnaires were subsequently distributed among the capital cities and all the others on the basis of their resident population. The poll stations, where the interviews were conducted, were randomly chosen.
}

includes 2,341 cases $^{7}$, the 2017 primary 3,699 and, finally, in 2019 there were 2,541 cases. The questionnaire provides information on the sociographic and political characteristics of the selectors, with a particular focus on their attitude toward the party and motivations behind their choice of vote.

The exit poll among the selectors in 2013, 2017, and 2019 captured the voting motivations by resorting to the following question: "What is the main motivation that led you to choose your candidate?" Respondents were able to choose between one of the following options: 1 . He/she represents my political values better than others; 2 . He/she represents the ideals of the PD better than the others; 3 . His/her personal characteristics; 4. I want someone who can win the next general election. ${ }^{8}$ Each option explicitly recalls the four possible motivations described in the previous paragraph: adherence to the voter values, adherence to the party values, the candidate's personal characteristics, and the candidate's electability.

Before proceeding with the selectors' profile based on the voting motivations, it could be useful to show how the different motivations were distributed among the selectors during the three leadership primaries under examination.

In this regard, Table 1 shows how the relative majority of selectors interviewed in the three primaries have chosen the candidate who can best reflect their personal values. Conversely, the strategic choice, which was based on the candidate's ability to lead the party to victory in the general election, involved a minority of selectors (19.5\%). Overall, the motivations related to party and personal values applied to $54.5 \%$ of the selectors. The strategic motivation or the motivation related to the personal traits of the candidate, on the other hand, helped determine the vote of $45.5 \%$ of the participants in the three primaries.

Looking at each primary, some differences emerge. To begin with, in the 2013 primaries (won by Matteo Renzi who became the party leader for the first time), more than $30 \%$ of the considered selectors had relied on their preferred candidate's ability to win the general election. Perceived electability was indicated by a much lower percentage of selectors, in both 2017 and 2019. Moreover, the percentage of selectors who indicated electability as their principal motivation in 2013 would have remained higher than in subsequent years even if we had not excluded the fifth option from the analysis (see Note 7 in this paragraph). ${ }^{9}$ It is quite surprisingly that the motivation based on electability has been so successful, as it was a leadership primary that occurred more than 4 years before the general election. In fact, the explanation should be traced back to the interweaving of the radical with the past, promoted by Matteo Renzi, and the disappointing results achieved by the PD, led by

\footnotetext{
${ }^{7} \mathrm{~A}$ total of 3,505 selectors were interviewed during the 2013 primaries. However, for reasons explained in note 11, 1,164 were excluded from the analysis. ${ }^{8}$ In 2013 it was possible to choose the option "I share his/her vision of the future of the PD". In order to make the 2013 questionnaire comparable with those of 2017 and 2019, we decided to exclude from the analysis the respondents who indicated that option.

${ }^{9}$ More specifically, if we had also considered the selectors who were motivated in their choice of vote on the basis of the candidate's vision of the PD future, then the percentage of those who had indicated electability would have been $20.2 \%$.
} 
TABLE 1 | Voting motivation in 2013, 2017, and 2019 leadership primaries (\% of respondents).

\begin{tabular}{|c|c|c|c|c|c|c|}
\hline Primaries & Personal values & Party values & Personalization & Electability & Total & $\mathbf{N}$ \\
\hline 2013 & 35.7 & 13.8 & 20.1 & 30.4 & 100 & 2303 \\
\hline 2017 & 36.1 & 16.5 & 30.0 & 17.3 & 100 & 3628 \\
\hline 2019 & 29.4 & 32.4 & 25.6 & 12.6 & 100 & 2492 \\
\hline Total & 34.0 & 20.5 & 26.0 & 19.5 & 100 & 8423 \\
\hline
\end{tabular}

Source, Own elaboration on Candidate and Leader's Selection data.

Pierluigi Bersani, in the general election of February 2013. Renzi was perceived as the one who could revive the party's electoral fortunes. It is, therefore, not surprising that $93.1 \%$ of those who based their vote on the electability of the candidate chose the former Prime Minister.

Compared to 2013, the relationship between electability and personalization was reversed in 2017, while the percentages of selectors who made their decisions by referring to their personal values and party ideals remained substantially unchanged. If the candidate's ability to represent selector values and to win the general election (as well as his vision of the PD's future) prevailed in 2013, in 2017, we find that the candidate's personal traits combined with his ability to represent the values of the selectors play a large part. More specifically, in this case, $30 \%$ of the selectors declare that they base their choice on the personal characteristics of the candidate. In an election context that is largely unfavorable to Democrats, the selectors are mainly concerned with respect for their values and the characteristics of the leader, caring less about the general election and even less for the values of the party (Seddone and Sozzi, 2018). The driving force of the personalization was no different for Renzi's and Orlando's supporters, while, in contrast, it was less relevant among Emiliano's selectors, where motivations based on personal and party values applied to $73 \%$ of the supporters.

Nevertheless, in 2017, the issues relating to values and the representation of the party's ideals contributed to determining the vote of $52.6 \%$ of selectors. In 2019 this percentage reached $61.8 \%$ and, for the first time, the selectors that based their voting choice on party values prevailed, forming $32.4 \%$ of the participants. This particularly interesting fact identifies the difference between the 2017 and 2019 primaries. The first one has been useful to Renzi for regrouping the party around his figure after the disappointment of the constitutional referendum (Pasquino and Valbruzzi, 2017). The second one was aimed at redefining the internal balance of the party, starting from the repositioning of the intra-party factions which were forsaken by Renzi and shaken by the heavy defeat in the parliamentary elections of March 2018. In this context, the selectors, many of whom had only 2 years earlier once again trusted Renzi, re-trusted the party's collective identity (Seddone, 2019). Finally, it should be stressed that personalization and electability are both minority motivations and are distributed among the three candidates. More specifically, the motivation of electability was a little more favored among Zingaretti's selectors (14.7\%), compared with both Martina's (8.8\%) and Giachetti's selectors (7.2\%). However, the most important difference concerns Giachetti (a candidate closely linked to Renzi) and the fact that among his supporters, the motivation linked to the voter's personal values prevailed (41\%), while among Zingaretti's and Martina's supporters the reference to party values prevailed.

As we have already pointed out, selectors can be grouped into four categories on the basis of the motivation behind their voting behavior. By combining this classification with sociographic and political information about individual voters, it is possible to draw a profile of the selectors according to their chosen motivation. We can, therefore, understand whether, for example, the selectors who place the emphasis on party values are younger than those who look at electability or whether the latter are more educated than those who consider the candidate's personal traits. In addition, with regard to voting motivation, we can determine whether there are differences in those who voted for the frontrunner candidate, depending on whether they are loyal selectors (i.e., willing to vote $\mathrm{PD}$ regardless of the outcome of the primaries) or defectionist selectors (i.e., those whose vote for the PD depends on the outcome of the primaries).

From Table 2, we can see how female gender selectors are over-represented among those who chose hard motivations, such as electability and personalization. Conversely, men (who make up almost $60 \%$ of the participants) are over-represented among those who based their voting decision on personal values and, above all, the ideals of the party.

Regarding the age of the selectors, there is a tendency showing that as age increases, there is an overrepresentation of those who make their decision on the basis of the electability of the candidate and, especially on the basis of his/her personal characteristics. If we compare the three competitions under examination, this dynamic has no significant differences. This trend is clearly contrary to our hypothesis. The only notable exception concerns 2013, when occurred an overrepresentation of over$65 \mathrm{~s}$ among those who are motivated to vote by referring to the ideals of the party. In particular, those older voters who strongly identified with the PD feared the effects of Renzi's victory and, therefore, in $55.8 \%$ of cases opted for the leftist, Gianni Cuperlo, a percentage far higher than the $18.2 \%$ collected overall by the representative of the leftist faction of the party. The Renzi's threat disappeared in 2017, when older people, the most willing to follow the indications of the PD factions, became Renzi's supporters. While younger selectors, motivating their vote mainly on an ideological-value basis, seemed to ask for a return of the party to the pre-Renzi phase. ${ }^{10}$

\footnotetext{
${ }^{10} \mathrm{To}$ confirm this, it is worth pointing out that: firstly, the percentage of Renzi selectors over 65 was $45 \%$ in 2017 and $29.8 \%$ in 2013; secondly, the percentage of Renzi selectors aged between 16 and 34 was 13\% in 2017 and 29\% in 2013.
} 
TABLE 2 | Socio-political profile of the PD selectors based on voting motivation (\% of respondents).

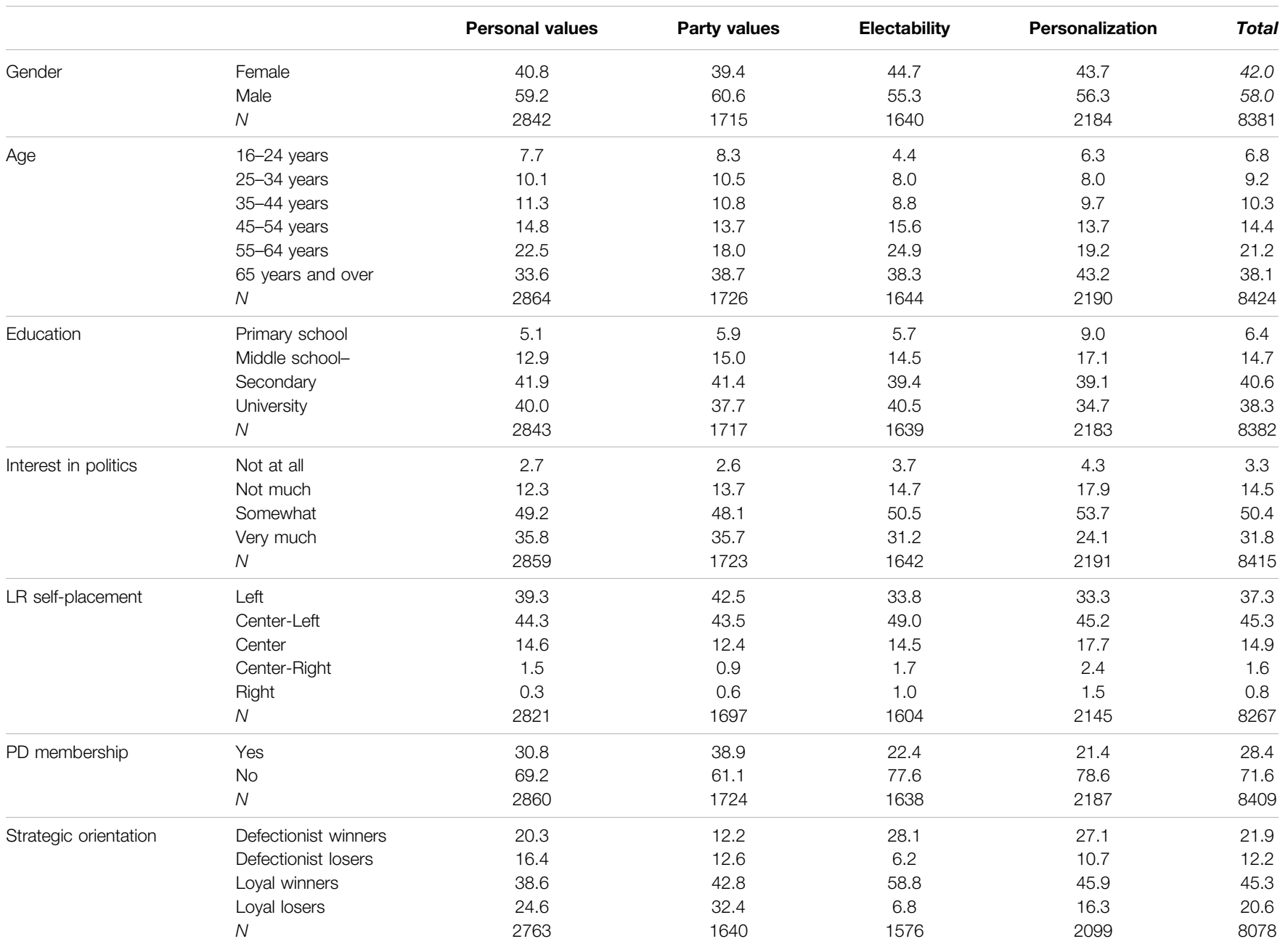

Source, Own elaboration on Candidate and Leader's Selection data.

Concerning the level of education, in accordance with our expectations, it can be seen that among the less educated selectors there is an overrepresentation of those consider the personal traits of the candidates when they vote. However, in relation to the same motivation, selectors with university-level education are underrepresented. The motivations related to personalization are particularly appreciated by the less educated selectors in all three respective elections. In contrast, on all three occasions, especially in 2013 and 2017, those with university education have a relative propensity to choose by looking at the electability of candidates.

In general terms, from a sociographic perspective, we can, therefore, say that the motivations linked to party ideals and personal values attract male and young people more than the overall figure, while they are distributed quite evenly in relation to the level of education. In contrast, electability reasons attract relatively more women, people aged $45-64$, and selectors with a university education. Further, the personal traits of candidates are relatively more attractive to women (but to a small extent), over$65 \mathrm{~s}$, and poorly educated selectors.

Interest in politics is the first political variable under consideration. As can be seen, in line with our hypothesis, those who are little or not at all interested are over-represented among the hard motivations, especially concerning electability. In contrast, the interested selectors are over-represented in terms of both personal and party values. These trends are repeated with few and negligible differences in all three primary elections considered.

Regarding the self-positioning of selectors on the left-right axis, in line with the expectations, it should be firmly pointed out that left-wing selectors are over-represented among those who have indicated motivations related to the personal values and ideals of the party. Center-left selectors, on the other hand, are distributed in a rather balanced way, with a slight overrepresentation in relation to the electability motivation. The rest of the selectors (who make up only $17.3 \%$ of the sample) tend to be over-represented on hard motivations. Centrists, in particular, are over-represented among those who chose based on the candidate's personal traits and underrepresented in relation to party values. In 2013 and 2017 there were no particular differences from the pooled figure. For example, the propensity to attach great importance to electability for center-left selectors was confirmed, although in 2013 this was accompanied by an underrepresentation in relation to soft motivations, while in 2017 there was a slight overrepresentation also in relation to personal values. This 
indicates that during Renzi's leadership, the party has continued to lose ground among the PD's electoral base. In 2019, on the other hand, there was an overrepresentation of the center-left selectors among those who decided on the basis of party values (as well as on the basis of electability). This indicates that after the Renzi phase, there was a return to the party by a significant share of selectors (Rombi et al., 2019).

Party membership is another important variable potentially able to distinguish selectors according to their voting motivations. In fact, Table 2 shows that, as we predicted, PD members are overrepresented in soft motivations related to personal and party values, while non-members show opposite tendencies, being over-represented in the motivations related to electability and personalization. Moreover, this trend does not show any particular differences between the three competitions in question.

The last political variable that we included in the analysis is "strategic orientation". Defectionist winners, who make up 21.9\% of the sample, are over-represented among those who use the electability of the candidate and his/her personal traits as a voting criterion. Unsurprisingly, they are largely underrepresented among those who base their voting choice on the party's ideals. In contrast, defectionist losers (12.2\%) are over-represented among those who consider the candidate's level of adherence to the selector's personal values to be the most important voting motivation. Conversely, they are underrepresented in relation to hard reasons, such as the electability of the candidate and his/her personal characteristics. Regarding the selectors who declare themselves loyal to the PD regardless of the outcome of the primaries, we can see that those who voted for the winner of the competition (45.3\%) are over-represented with reference to the electability of the candidate, while they are underrepresented in relation to personal values. Further, loyal losers (20.6\%) are underrepresented among the hard motivations and overrepresented among the soft ones, especially regarding party values. In relation to this variable, our hypothesis is not confirmed. Renzi's candidacy in 2017 and, especially, 2013 gave centrality to the dimension of electability. The main objective of Renzi's selectors, regardless of whether they had a loyal or defectionist attitude towards the PD, was the victory of the following elections, especially in 2013, when the PD came from unsatisfactory parliamentary elections. This mechanism is confirmed, by opposition, by the fact that in 2019-when the Renzi's phase was ending-its functioning began to fail.

To better clarify the theme, we can note the differences between the three primaries. Even in the case of strategic orientation, those differences can mark a certain divergence between the primaries won by Renzi (2013 and 2017) and those of 2019. In 2013 and 2017, the trends are similar to those emerging from the pooled analysis. In 2013, we only need to highlight a much higher overrepresentation than that recorded in the pooled analysis of "loyal winners" among selectors whose vote is motivated by electability and the "loyal losers" among those who vote based on party values. ${ }^{11}$ First, in

\footnotetext{
${ }^{11}$ In the first case, loyal winners accounted for $59.7 \%$ compared with $37.4 \%$ in the sample. In the latter case, loyal losers accounted for $52.7 \%$ compared with a $23.3 \%$ incidence in the sample.
}

2019 , the "defectionist losers" are underrepresented in relation to party values, mainly because of the attitudes of the voters of Giachetti, a member of the Renzi area of the party, considered far from attractive by most of the identitarian voters. Second, there is an overrepresentation of "loyal winners" not only in terms of electability but also among those who justify their choice of vote by referring to the ideals of the party. This situation, moreover, cannot be surprising considering the strong identity profile (in open contrast with the Renzi experience) of Nicola Zingaretti, the winner of the competition.

\section{WHY DO VOTERS THINK THIS WAY? A MULTINOMIAL ANALYSIS}

The description of the relationship between the main sociopolitical peculiarities of the selectors and their voting motivations has revealed significant affinities and differences. However, to deepen and explain the reasons behind the choice of voting of the selectors, we should provide an inferential model. The categorical dependent variable of the model consists of the voting motivations and is divided into four modalities, each corresponding to an option in the questionnaires: personal values, party values, electability, and personalization. Just as in the case of the dependent variable, the independent variables (that are all categorical variables) also correspond to those used for the descriptive analysis (see Table 2). The model also includes a control variable aimed at considering the influence of the electoral context and indicating whether the respondent has been interviewed in 2013, 2017, or 2019.

If we are dealing exclusively with categorical variables, the analysis should be based on a multinomial logistic regression model in which the effects of each variable are estimated using odds ratio. A test of the model with the eight independent variables in contrast with the model that includes only the constant is statistically significant (chisquare $=1553.50, p<0.0001)$. Given that almost all the variables are categorical with more than two modalities, the model considers one of the categories for each variable as a reference one. More precisely, for both the dependent and independent variables, the reference category is the last one (Field 2009). In the case of the dependent variable, we have considered the category "personalization" as a basis for comparing the other three.

Table 3 shows that numerous categories are statistically significant $(p<0.05)$. As we can see, regarding the motivations based on the candidate's personal traits, the statistically significant categories associated with an increased chance of basing the vote on personal values are all age groups except 35-44 year olds, all categories related to self-positioning on the left-right axis in relation to the reference category consisting of those who are positioned on the right, and defectionist losers in relation to the reference category consisting of loyal losers. Conversely, the categories associated with a decreased chance of basing the vote on personal values are as follows: having a low level of education (primary and middle school), all levels of interest in politics in relation to those who are 
TABLE 3 | Multinomial logistic model-Explaining selectors'motivations.

\begin{tabular}{|c|c|c|c|c|c|c|c|c|c|c|}
\hline & & \multicolumn{3}{|c|}{ Personal values } & \multicolumn{3}{|c|}{ Party values } & \multicolumn{3}{|c|}{ Electability } \\
\hline & & Odds ratio & SE & Sig & $\begin{array}{l}\text { Odds } \\
\text { ratio }\end{array}$ & SE & Sig & $\begin{array}{l}\text { Odds } \\
\text { ratio }\end{array}$ & SE & Sig \\
\hline \multirow[t]{2}{*}{ Gender } & Female & 0.926 & 0.062 & & 0.935 & 0.071 & & 1.055 & 0.071 & \\
\hline & Male $^{a}$ & - & - & - & - & - & - & - & - & - \\
\hline \multirow[t]{6}{*}{ Age } & $16-24$ & 1.519 & 0.131 & 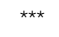 & 1.692 & 0.146 & $\star \star \star ~$ & 0.742 & 0.171 & * \\
\hline & $25-34$ & 1.316 & 0.117 & $\star \star$ & 1.317 & 0.133 & $\star \star$ & 0.886 & 0.142 & \\
\hline & $35-44$ & 1.205 & 0.109 & * & 1.129 & 0.125 & & 0.810 & 0.132 & \\
\hline & $45-54$ & 1.232 & 0.097 & $\star \star$ & 1.046 & 0.114 & & 1.102 & 0.111 & \\
\hline & $55-64$ & 1.370 & 0.083 & $\star \star \star \star ~$ & 1.031 & 0.098 & & 1.287 & 0.094 & 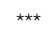 \\
\hline & 65 and over ${ }^{a}$ & - & - & - & - & - & - & - & - & - \\
\hline \multirow[t]{4}{*}{ Education } & Primary school & 0.590 & 0.133 & 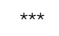 & 0.740 & 0.153 & $\star \star$ & 0.517 & 0.154 & 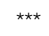 \\
\hline & Middle school & 0.706 & 0.096 & 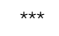 & 0.899 & 0.110 & & 0.656 & 0.110 & 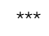 \\
\hline & Secondary & 0.912 & 0.070 & & 0.990 & 0.081 & & 0.798 & 0.082 & 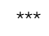 \\
\hline & University $^{a}$ & - & - & - & & & & - & - & - \\
\hline \multirow[t]{4}{*}{ Interest in politics } & Not at all & 0.573 & 0.179 & 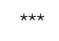 & 0.582 & 0.221 & $\star \star$ & 0.562 & 0.214 & 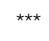 \\
\hline & Not much & 0.563 & 0.100 & 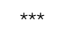 & 0.800 & 0.111 & * & 0.653 & 0.115 & $\star \star \star$ \\
\hline & Somewhat & 0.697 & 0.071 & $\star \star \star \star ~$ & 0.782 & 0.082 & 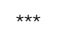 & 0.723 & 0.084 & 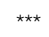 \\
\hline & Very much ${ }^{a}$ & - & - & - & - & - & - & - & - & - \\
\hline \multirow[t]{5}{*}{ LR self-placement } & Left & 5.086 & 0.392 & 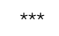 & 2.332 & 0.376 & $\star \star$ & 1.186 & 0.337 & \\
\hline & Center-Left & 4.406 & 0.391 & $\star \star \star \star ~$ & 1.864 & 0.376 & * & 1.182 & 0.336 & \\
\hline & Center & 4.270 & 0.395 & 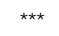 & 1.524 & 0.383 & & 0.941 & 0.343 & \\
\hline & Center-Right & 2.970 & 0.444 & $\star \star$ & 0.942 & 0.489 & & 0.667 & 0.421 & \\
\hline & Right $^{a}$ & - & - & - & - & - & - & - & - & - \\
\hline \multirow[t]{2}{*}{ Pd member } & No & 0.739 & 0.073 & $\star \star \star ~$ & 0.502 & 0.081 & 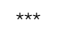 & 1.002 & 0.088 & \\
\hline & $Y_{e s}^{a}$ & - & - & - & - & - & - & - & - & - \\
\hline \multirow{4}{*}{$\begin{array}{l}\text { Strategic } \\
\text { orientation }\end{array}$} & Defectionist winners & 0.571 & 0.095 & 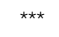 & 0.315 & 0.114 & $\star \star \star ~$ & 2.825 & 0.136 & 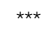 \\
\hline & Defectionist losers & 1.119 & 0.112 & & 0.885 & 0.128 & & 1.394 & 0.175 & * \\
\hline & Loyal winners & 0.608 & 0.083 & 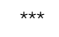 & 0.522 & 0.089 & $\star \star \star ~$ & 3.754 & 0.125 & 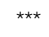 \\
\hline & Loyal losers $^{a}$ & - & - & - & - & - & - & - & - & - \\
\hline \multirow[t]{3}{*}{ Electoral Context } & Primary 2013 & 1.471 & 0.086 & 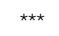 & 0,497 & 0.098 & 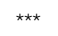 & 3.930 & 0.100 & 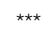 \\
\hline & Primary 2017 & 1.103 & 0.074 & & 0,440 & 0.081 & 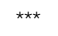 & 1.316 & 0.093 & 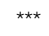 \\
\hline & Primary $2019^{a}$ & - & - & - & - & - & - & - & - & - \\
\hline Constant & & -0.555 & 0.409 & & 0.744 & 0.086 & & -1.578 & 0.376 & 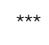 \\
\hline $\mathrm{N}$ & & 2.679 & & & 1.591 & & & 1.533 & & \\
\hline
\end{tabular}

Note: ${ }^{* *} \mathrm{p}<0.01,{ }^{* *} \mathrm{p}<0.05,{ }^{*} \mathrm{p}<0.1$; dependent variable: type of motivation (personal values, party values, electability, and personalization as a reference category); a $=$ reference category. The value for the constant is the $\beta$ coefficient.

very interested (reference category), not being PD members, and being defectionist and loyal winners.

Regarding the second type of motivation, it is evident that the statistically significant categories associated with an increased chance of basing the vote on party values are as follows: being between the ages of 16 and 34 and aligning yourself on the left of the left-right axis. The categories associated with a decreased chance of basing the vote on party values are as follows: having a low level of education (primary school), having some interest in politics, not being a PD member, and being defectionist and loyal winners.

Finally, the statistically significant categories associated with an increased chance of basing the vote on the candidate's electability are as follows: first, being between 55 and 64 years of age; second, being defectionist winners; and third, being loyal winners. In contrast, the categories associated with a decreased chance of basing the vote on a candidate's electability are as follows: having an elementary certificate, secondary certificate, or a diploma as opposed to a university-level education (reference category); and being only slightly or not at all interested in politics, compared with being greatly interested (reference category).

Having identified the variables and their categories, helpful in explaining the selectors' behavior and, in particular, their adherence to one or another type of motivation, it seems useful to look at the most statistically important ones, focusing, in particular, on political variables.

To begin with, we should emphasize that, compared to those on the right, leftist and center-leftist selectors are more likely to motivate their vote based on their personal values being greater than more than 5 times the former and about 4.5 times the second, referencing the same types of selectors who motivate their vote based on the personal characteristics of the candidate (reference category of the dependent variable). However, not being PD members reduces by $30 \%$ the probability of voting based on the voter's personal values, compared with being PD 
members. Moreover, compared to being greatly interested, being at all or only slightly interested in politics reduces the probability of voting based on personal values by between 43 and $30 \%$.

Even the strategic orientation of the selector provides a relevant explanation for the reasons behind the choice of vote. As can be seen from Table 3, those who have a defectionist orientation toward the party and are voters of the competition's winner are less likely to have built their decision on the level of representation of their personal values. The same goes for those who have a loyal attitude toward the PD. Compared to loyal losers, this percentage is $43 \%$ lower for defectionists and $39 \%$ lower for loyals. Given the small difference between defectionists and loyals, the most important element is the selectors' voting orientation.

Regarding the party's ideals, in the first instance, we should mention an analogy with the selectors who have indicated "personal values" as their main voting motivation. The attitude of these two groups of selectors is, in fact, essentially explained by the same variables. However, it is worth delving into the subject further as some differences exist, mainly relating to the intensity of the effect of the categories. In this case, for example, compared to being on the right, positioning yourself on the left increases the probability of motivating your vote based on the candidate's ability to represent the ideals of the party, by about twice. Quite predictably, compared to being a member of the PD, not being enrolled reduces the probability of motivating the vote according to the party's ideals by $50 \%$. Even in relation to this motivation, defectionist and loyal winners are less likely than loyal losers to motivate their vote on party ideals. This percentage is about $70 \%$ lower in the first case and about $50 \%$ in the second case. Voting for the winning candidate (for both defectionists and loyals) lowers the likelihood of voting based on party ideals, compared with those who vote for one of the defeated candidates and declared themselves loyal to the party.

\section{CONCLUSION}

Although the analysis of the determinants of electoral behavior is a pillar of political science, systematic research into the behavior of selectors, i.e., those who take part in the selection of a party leader or candidate for monocratic office, is rare. This article has helped bridge this gap by examining the voting motivations of participants in the direct election of the PD leader in 2013, 2017, and 2019. In particular, the analysis has focused on the identification of sociographic and, above all, political variables that push a selector to motivate his/her vote on the basis of one of

\section{REFERENCES}

Abramowitz, A. I. (1989). Viability, Electability, and Candidate Choice in a Presidential Primary Election: A Test of Competing Models. J. Polit. 51, 977-992. doi:10.2307/2131544

Abramson, P. R., Aldrich, J. H., Paolino, P., and Rohde, D. W. (1992). "Sophisticated" Voting in the 1988 Presidential Primaries. Am. Polit. Sci. Rev. 86, 55-69. doi:10.2307/1964015 the four possible motivations taken into account: personal values, party values, electability, and personalization.

The descriptive analysis has shown that selectors who base their vote on reasons such as personal or party values are relatively younger, more educated, more interested in politics, tending to be left-wing, members of the $\mathrm{PD}$, and with a greater propensity to support one of the defeated candidates while being loyal to the party, especially in the case of those reliant on party values. Selectors who motivate their vote by referring to the electability of the candidate or his personal characteristics have a different profile. In both cases, these are relatively older voters, less interested in politics, more centrists (i.e., center-leftists for the former and centrists for the latter), and with a greater propensity to support the winner. Moreover, those reliant on electability are relatively more educated and loyal to the party, while those reliant on personalization are less educated and tend to defect.

These trends have been confirmed by a multivariate analysis, which has highlighted the importance of both the self-positioning on the left-right axis and the strategic orientation in explaining the reasons that lead a selector to base his/her vote on one motivation rather than another.

The analysis has also revealed the relevance of the political context, where it has been shown that compared with 2019, the 2013, and 2017 primary elections are characterized by two elements. First, by a greater propensity of the selectors to motivate the vote on the basis of the electability of the candidate and on his personal characteristics. Second, by a lower propensity of selectors to choose based on the candidates' ability to represent party ideals. A clear break, therefore, exists between the Renzi phase of the PD and that inaugurated by Zingaretti, which, although interrupted early in March 2021, marked a return to the party, to its ideals, and to its collective identity, both by its voters and sympathizers and by its main leaders.

\section{DATA AVAILABILITY STATEMENT}

The raw data supporting the conclusions of this article will be made available by the authors, without undue reservation.

\section{AUTHOR CONTRIBUTIONS}

The author confirms sole responsibility for the following: study conception and design, data collection, analysis and interpretation of results, and manuscript preparation.

Barker, D. C., Lawrence, A. B., and Tavits, M. (2006). Partisanship and the Dynamics of "Candidate Centered Politics" in American Presidential Nominations. Elect. Stud. 25, 599-610. doi:10.1016/j.electstud.2005.09.001

Bartels, L. (2000). Partisanship and Voting Behavior, 1952-1996. Am. J. Polit. Sci. 44, 32-50. doi:10.2307/2669291

Blumenstiel, J. E., and Plischke, T. (2015). Changing Motivations, Time of the Voting Decision, and Short-Term Volatility - the Dynamics of Voter Heterogeneity. Elect. Stud. 37, 28-40. doi:10.1016/ j.electstud.2014.11.003 
Calise, M. (2016). La Democrazia Del Leader. Rome-Bari: Laterza, 159.

Carreri, L. (2019). "Selettori strategici e non ideologici: un'analisi dell'electability dei candidati alla Segreteria del PD," in L'elezione di Zingaretti. Editors S. Rombi and F. Serricchio (Novi Ligure: Edizioni Epoké), 203-214.

Cavataio, M., and Fasano, L. (2013). "L'immagine dei candidati. Come logica di voto, viability e electability influenzano il successo alle primarie," in Perdere Vincendo. Dal Successo Delle Primarie 2012 All'impasse post-elettorale. Editors B. Gelli, T. Mannarini, and C. Talò (Milano: Franco Angeli), 146-167.

Dalton, R. J., and Klingemann, H. D. (2007). "Citizens and Political Behavior," in The Oxford Handbook of Political Behavior. Editors R.J. Dalton and H.D. Klingemann (Oxford: Oxford University Press), 3-23.

De Luca, R., and Fasano, L. (2018). Il Partito Democratico dei nativi. Novi Ligure: Edizioni Epoké, 210.

Eberl, J.-M., Wagner, M., and Boomgaarden, H. G. (2017). Are Perceptions of Candidate Traits Shaped by the media? the Effects of Three Types of media Bias. Int. J. Press Polit. 22, 111-132. doi:10.1177/1940161216674651

Esser, F., and Strömbäck, J. (2004). Mediatization of Politics. Understanding the Transformation of Western Democracies. London: Palgrave Macmillan, 246.

Field, A. (2009). Discovering Statistics with SPSS. London: Sage, 821.

Ford, R., and Jennings, W. (2020). The Changing Cleavage Politics of Western Europe. Annu. Rev. Polit. Sci. 23, 295-314. doi:10.1146/annurev-polisci-052217-104957

Garzia, D. (2014). Personalization of Politics and Electoral Change. London: Palgrave Macmillan, 137.

Ignazi, P. (2019). Partito e democrazia: L'incerto percorso della legittimazione dei partiti. Bologna: il Mulino, 438.

Lau, R. R., and Redlawsk, D. P. (2001). Advantages and Disadvantages of Cognitive Heuristics in Political Decision Making. Am. J. Polit. Sci. 45, 951-971. doi:10.2307/2669334

Lewis-Beck, M., Nadeau, R., and Elias, A. (2008). Economics, Party, and the Vote: Causality Issues and Panel Data. Am. J. Polit. Sci. 52, 84-95. doi:10.1111/j.15405907.2007.00300.x

Manin, B. (1997). The Principles of Representative Government. Cambridge: Cambridge University Press, 254.

Markus, G. B., and Converse, P. E. (1979). A Dynamic Simultaneous Equation Model of Electoral Choice. Am. Polit. Sci. Rev. 73, 1055-1070. doi:10.2307/ 1953989

Markus, G. B. (1982). Political Attitudes during an Election Year: A Report on the 1980 NES Panel Study. Am. Polit. Sci. Rev. 76, 538-601. doi:10.2307/1963730

Mazzoleni, G., and Schulz, W. (1999). "Mediatization" of Politics: A Challenge for Democracy? Polit. Commun. 16, 247-261. doi:10.1080/105846099198613

McAllister, I. (2007). "The Personalization of Politics," in The Oxford Handbook of Political Behavior. Editors R.J. Dalton and H.D. Klingemann (Oxford: Oxford University Press), 571-588.

Minaldi, G., and Soare, S. (2018). "Strategie di voto e percezione dei candidati. Validità partitca e competitività alle elezioni generali, dal breve al lungo termine," in Il Partito Democratico dei nativi. Editors R. De Luca and L. Fasano (Novi Ligure: Edizioni Epoké), 135-146.

Noelle-Neumann, E. (1993). The Spiral of Silence: Public Opinion-Our Social Skin. Chicago: The Chicago University Press.

Norris, P. (1999). Critical Citizens. Global Support for Democratic Government. Oxford: Oxford University Press, 303.

Ohr, D., and Oscarsson, H. (2011). "Leader Traits, Leader Image, and Vote Choice," in Political Leaders and Democratic Elections. Editors K. Aarts, A. Blais, and H. Schmitt (Oxford: Oxford University Press), 187-214.

Pasquino, G. (2009). Il Partito Democratico. Elezioni del segretario, organizzazione e potere. Bologna: Bononia University Press, 256.

Pasquino, G., and Venturino, F. (2010). Il Partito Democratico di Bersani. Persone, profilo e organizzazione. Bologna: Bononia University Press, 236.

Pasquino, G., and Venturino, F. (2014). Il Partito Democratico Secondo Matteo. Bologna: Bononia University Press, 244.

Pasquino, G. (2016). Primaries, Parties, People. Contemp. Ital. Polit. 8, 103-111. doi:10.1080/23248823.2016.1147217

Pasquino, G., and Valbruzzi, M. (2017). Italy Says No: the 2016 Constitutional Referendum and its Consequences. J. Mod. Ital. Stud. 22, 145-162. doi:10.1080/ 1354571x.2017.1286096

Peacock, C., Dugger, H., Fanelli, J. K., Harris, A. J., McLelland, J. B., and Richardson, L. A. (2021). Choosing a Candidate: Traits, Issues, and
Electability. Am. Behav. Scientist 65, 540-557. doi:10.1177/ 0002764220978458

Poguntke, T., and Webb, P. (2005). The Presidentialization of Politics: A Comparative Study of Modern Democracies. Oxford: Oxford University Press, 376.

Rickershauser, J., and Aldrich, J. H. (2007). "It's the Electability, Stupid" - or Maybe Not? Electability, Substance, and Strategic Voting in Presidential Primaries. Elect. Stud. 26, 371-380. doi:10.1016/j.electstud.2006.09.003

Rombi, S., and Serricchio, F. (2019). L'elezione di Zingaretti. La rivincita del partito? Novi Ligure: Edizioni Epoké, 250.

Samuels, D. J., and Shugart, M. S. (2010). Presidents, Parties, and Prime Ministers. How the Separation of Powers Affects Party Organization and Behavior. Cambridge: Cambridge University Press, 295.

Sandri, G., and Seddone, A. (2015). The Primary Game. Primary Elections and the Italian Democratic Party. Novi Ligure: Edizioni Epoké, 187.

Scarrow, S. E. (2014). Beyond Party Members: Changing Approaches to Partisan Mobilization. Oxford: Oxford University Press, 256.

Seddone, A. (2019). "Le ragioni dietro la scelta del leader," in L'elezione di Zingaretti. Editors S. Rombi and F. Serricchio (Novi Ligure: Edizioni Epoké), 77-89.

Seddone, A., Sandri, G., and Sozzi, F. (2020). "Primary Elections for Party Leadership in Italty," in Innovations, Reinvented Politics and Representative Democracy. Editors A. Alexandre-Collier, A. Goujon, and G. Gourgues (London: Routledge), 46-59.

Seddone, A., and Sozzi, F. (2018). "The leader I want! L'analisi delle motivazioni di voto alle elezioni del leader del PD," in Il Partito Democratico dei nativi. Editors R. De Luca and L. Fasano (Novi Ligure: Edizioni Epoké), 81-93.

Simas, E. N. (2017). The Effects of Electability on US Primary Voters. J. Elections Public Opin. Parties 27, 274-290. doi:10.1080/17457289.2016.1270287

Smith, D. N., and Hanley, E. (2018). The Anger Games: Who Voted for Donald Trump in the 2016 Election, and Why? Crit. Sociol. 44, 195-212. doi:10.1177/ 0896920517740615

Sozzi, F. (2015). "Choosing the Party Leader: Are Voters' Motivations Shaped by Tradition, Strategy or Identification," in The Party Game. Editors G. Sandri and A. Seddone (Novi Ligure: Edizioni Epoké), 107-127.

Steger, W. P. (2003). Presidential Renomination Challenges in the 20th Century. Presidential Stud. Q. 33, 827-852. doi:10.1046/j.0360-4918.2003.00086.x

Steger, W. P. (2007). Who Wins Nominations and Why?. Polit. Res. Q. 60, 91-99. doi:10.1177/1065912906298597

Van Spanje, J., and De Vreese, C. (2011). So What's Wrong with the EU? Motivations Underlying the Eurosceptic Vote in the 2009 European Elections. Eur. Union Polit. 12, 405-429. doi:10.1177/1465116511410750

Venturino, F. (2019). "Le Regole Delle Primarie," in L'elezione di Zingaretti. Editors S. Rombi and F. Serricchio (Novi Ligure: Edizioni Epoké), 21-33.

Venturino, F., and Seddone, A. (2020). The Politics of Loyalty: Understanding Voters' Attitudes After Primary Elections. Gov. Oppos., 1-20. doi:10.1017/gov.2020.24

Wattenberg, M. P. (1990). "From a Partisan to a Candidate-Centered Electorate," in The New American Political System. Editor A. King (Washington: American Enterprise Institute), 139-174. doi:10.1007/978-1-349-12337-7_5

Conflict of Interest: The author declares that the research was conducted in the absence of any commercial or financial relationships that could be construed as a potential conflict of interest.

Publisher's Note: All claims expressed in this article are solely those of the authors and do not necessarily represent those of their affiliated organizations, or those of the publisher, the editors and the reviewers. Any product that may be evaluated in this article, or claim that may be made by its manufacturer, is not guaranteed or endorsed by the publisher.

Copyright $\odot 2021$ Rombi. This is an open-access article distributed under the terms of the Creative Commons Attribution License (CC BY). The use, distribution or reproduction in other forums is permitted, provided the original author(s) and the copyright owner(s) are credited and that the original publication in this journal is cited, in accordance with accepted academic practice. No use, distribution or reproduction is permitted which does not comply with these terms. 